\title{
DEGENERATION OF THE GRANULAR LAYER OF THE CEREBELLUM
}

\author{
BY
}

\section{A. D. LEIGH and A. MEYER}

\section{From the Department of Neuropathology, Institute of Psychiatry, Maudsley Hospital, London}

The following investigation was initiated by the observation by one of us (Meyer, 1944), of a selective degeneration of the granular layer of the cerebellum in a case of a Wernicke syndrome associated with carcinoma of the stomach. The possible relation to one or other type of nutritional deficiency (not necessarily that of vitamin $B_{1}$ ) was discussed, but no consideration was given to the fact that there might be a more direct causal relation to the carcinoma. There has been a fair number of reports on cases of visceral carcinoma in which clinical and/or pathological signs of cerebellar degeneration (not associated with secondary deposits) were discovered. (Lhermitte, 1922 ; Casper, 1929 ; Scherer, 1933 ; Parker and Kernohan, 1933 ; Greenfield, 1934 ; Kennard, 1935 ; Zülch, 1936 ; Courville and Friedman, 1940; Alessi, 1940; Buchanan and others, 1947.) A causal relation between the carcinoma and the cerebellar lesion was by no means assumed in all of these communications. Indeed in the cases of Courville and Friedman, and Buchanan and others, it was expressly rejected in view of the clinical history. In the opinion of Brouwer and Biemond (1938), however, the rapid development of a cerebellar lesion in cases of carcinoma was such as to suggest the influence of a carcino-toxic agent. The granular layer, if involved, was not always selectively affected in their cases, but in the most important observations published on this subject by Bertrand and GodetGuillain (1942) the granular layer was indeed selectively involved. In fourteen out of sixteen cases of visceral carcinomata these authors described varying stages of degeneration of the granular layer, betraying itself even on macroscopic inspection by an appearance they termed "glacé." These cerebellar changes were most marked in the dorsal part of the vermis and were usually accompanied by degenerative signs in the inferior olives, particularly in their dorsal portion. This predilection for the dorsal aspects of the cerebellum recalls that seen in the delayed type of cerebellar atrophy (Foix and others, 1922), more recently known as parenchymatous cerebellar atrophy. This relationship, which is important in view of the usual age period of carcinoma, has in fact been discussed in the literature (Casper, 1929; Brouwer and Biemond, 1938). The latter authors concluded, however, that there was no relationship between the two conditions, as they found a diffuse distribution of the cerebellar changes in the carcinoma cases, as compared with the more focal distribution in the delayed atrophy. In the cases described by Bertrand and Godet-Guillain no clinical cerebellar signs were observed, and the authors considered, therefore, that the cerebellar lesions had developed rapidly during the terminal cachectic phase of the carcinomatous process.

Apart from the association with visceral carcinomata, a selective degeneration of the granular layer of the cerebellum has been attributed to a variety of causes. One of the first descriptions of the condition was given by Bielschowsky (1920) in infantile, late infantile, and juvenile cases of amaurotic idiocy. Since his description, this "cerebellopetal" type of degeneration has been regarded by many as the predominant type of cerebellar involvement in cerebro-macular degeneration. Norman (1940) showed that selective degeneration of the granular layer may also occur in mental defectives other than those suffering from amaurotic idiocy. Both his patients died from pulmonary tuberculosis, complicated in one by a terminal tuberculous enteritis. In this patient the terminal disease clearly preceded the onset of cerebellar signs. We mention this relationship because wasting diseases and, in particular, severe gastro-enteritis have been given some attention, especially in the older literature (Murri, 1900; Rossi, 1907 ; Archambault, 1918). Senile cachexia and malnutrition have also been discussed, particularly in relation to the delayed cerebellar atrophies of old age (Courville and Friedman, 1940). Diabetes mellitus has been noted in the literature as a possible cause. Shinosaki (1926), describing cerebellar changes in a case of severe congenital diabetes, clearly illustrated a selective degeneration of the granular layer. In keeping with views 
current at that time he discussed the possible causation of diabetes by lesions of the vermis, particularly of the uvula. One of Winkelman's (1943) cases of granular layer degeneration was a diabetic who died following an operation for acute gangrene of the intestinal tract and hæmorrhagic gastritis. The most important investigation in this field was carried out by Bertrand and Tiffenau (1942), who found a selective degeneration of the granules in the dorsal part of the cerebellum in five cases dying in diabetic coma, and in all cases the appearance and distribution were similar.

A more or less selective degeneration of the granular layer has also been described after prolonged experimental carbon-monoxide poisoning (Ferraro and Morrison, 1928), and in various toxiinfectious conditions, including lead, carbon monoxide, and histamine poisoning, inanition, and septicæmia (Williams, 1934). Two papers describing more recent experimental work require special mention. Upners (1939) administered thiophen $\left(\mathrm{C}_{4} \mathrm{H}_{4} \mathrm{~S}\right)$ to dogs in small doses over long periods, and found a selective action on the granular layer, resulting in its degeneration, usually combined with pathological changes in the quadrigeminal region resembling those seen in Wernicke's syndrome. In all the animals frequent vomiting and anorexia were conspicuous. Likewise the administration of methyl mercury compounds to rats and a monkey (Hunter and others, 1940) resulted in rapid loss of weight, followed by specific nervous disturbances. In the rats on which multiple observations were possible the peripheral nerves and posterior spinal roots were affected first, the posterior columns and granular layer of the middle lobes of the cerebellum later.

This review of the literature, though probably by no means complete, demonstrates that certain metabolic factors may be of importance in the pathogenesis, classification, and ætiology of certain cerebellar degenerations. It was for this reason that we considered a further investigation of the problem was justified.

\section{Material}

Our material consists of (1) fourteen cases of visceral carcinoma with or without metastases in brain and other organs. Eight of these showed a degeneration of the granular layer. The negative cases comprised patients suffering from a variety of visceral carcinomata (of rectum, stomach, œsophagus, gall bladder, bronchus, prostate).

(2) Six cases dying in diabetic or hypoglycæmic coma. Of these two were definite hyperglycæmic fatalities; in neither was there any cerebellar affection, although in one a complete olivary degeneration, and severe acute cell changes (lysis most marked in the third layer of the cerebrap cortex and of the parvo-cellular elements of the corpus striatum were present, similar to the changes described by Bertrand and Tiffenau (1942). Bottw cases are excluded from full description in this paper ; the remaining four include a case of doubt) ful hyperglycæmic coma, a diabetic dying from $\overrightarrow{\text { s. }}$ irreversible hypoglycæmia, and two schizophrenic with hypoglycæmia induced for therapeutic purposes? and dying in irreversible coma. The last three case? of proved hypoglycæmia were found in a tota material of nine cases of fatal hypoglycæmia.

(3) Four cases of amaurotic idiocy, all showing degeneration of the granular layer.

In all cases investigated for this paper a fulp histological investigation of the brain has been made by the usual methods.

\section{Group I : Visceral Carcinoma}

Case 1. - A man aged 62 years was the subject of $\dot{a}$ previous report by one of us (Meyer, 1944). He died after an illness of approximately twelve months' duratigni the clinical diagnosis being gastric carcinoma. TAis was confirmed at autopsy.

Autopsy Findings.-Macroscopically there was some thickening of the leptomeninges at the base of the brain $z$ particularly within the interpeduncular space. In the cerebellum there was no general reduction in size, bu傮 glassy appearance was noticed in what would corresp to the granular layer. Histologically, there were changes in the hypothalamus characteristic of Wernick encephalopathy. These changes, however, were atypical in so far as the glio-mesodermal proliferation was more conspicuous in the anterior part of the hypothalamu何 than in the mammillary bodies, which showed signs of a very recent affection only.

In the cerebellum a selective degeneration of th: granular layer was present. In Nissl preparations the Purkinje-cell layer contrasted prominently with the granular layer, the granules failing to stain with cresyb violet (Fig. 1). With high-power magnification, insteađ of the darkly-stained nuclei of the granules, with their well-defined chromatin, only the shadows of severelp. deformed nuclei in varying degrees of disintegration. were to be seen. The cytoplasm, normally not welf seen, appeared to merge with that of adjacent cells, thus producing what has aptly been termed "conglutination. 3 This process was found throughout the granular layer but was not quite so advanced in the ventromedial sectog as in the remaining sectors of the cerebellum.

In myelin preparations also, the ventral and especially ventromedial areas showed a better staining reaction in the granular layer, particularly near the summit of lobules. This was due to nuclear staining, which was in varying degrees deficient in the other parts of thes granular layer. The translucent appearance was not due to a diminution of the myelinated fibres, which though conspicuously beaded, were seen to traversê 


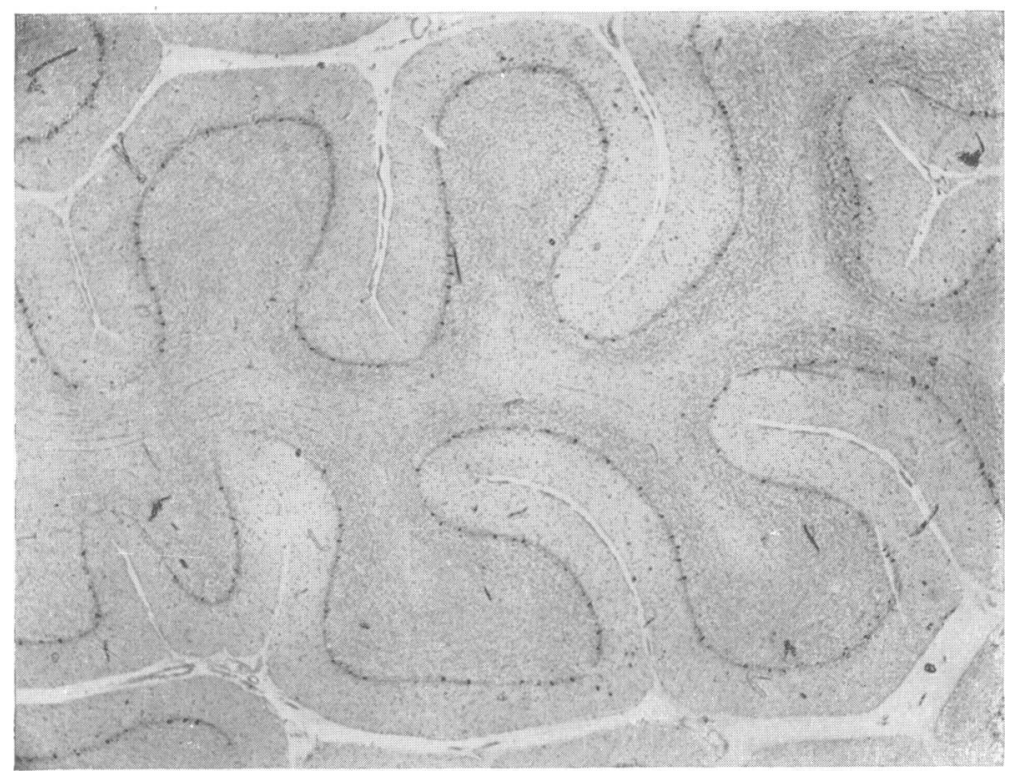

FIG. 1.-Diffuse degeneration of granular layer in a case of gastric carcinoma (Case 1). Nissl, $\times 18$.

this region in normal numbers. Bielschowsky silver preparations disclosed normal basket cells and processes, with no diminution in the fibres of the granular layer. The Bergmann glia contained an excess of lipoids, and much fat was also seen in the glia cells and mesodermal elements of the granular layer, and to a lesser degree in the white matter. No appreciable microglial proliferation was seen in Penfield preparations, nor was any fibrous gliosis revealed by the Holzer technique.

The dentate nucleus was little affected, save for an excess of lipofuscin in nerve cells and some degree of patchy glial proliferation. In the inferior olives it was immediately apparent with low magnification that there was a diminution of nerve cells, most marked in the dorsomedial corner of the nucleus. High-power inspection revealed that all nerve cells showed some pigment degeneration, but that in the dorsomedial portion the cells had become opaque discs, with the nuclei either dark and shrunken or breaking up into granules. In this region there was considerable gliomesodermal reaction, and in Holzer preparations a moderate diffuse glial fibrosis was seen. No demyelination was noted.

The blood vessels of brain and meninges showed moderate fibrosis, and in the cerebral white matter a rarefaction of tissue in close vicinity to the thickened vessels had produced the picture of small "criblures." Apart from this change, however, no significant abnormality was present in the cerebral hemispheres.

Case 2.-A man aged 67 was admitted to King's College Hospital with a six weeks' history of epigastric pain and loss of weight. His condition rapidly deteriorated, and he died two weeks after admission. The diagnosis was of carcinoma of the bladder, with metastatic deposits in the liver.
Autopsy Findings.-A squamous-celled carcinoma of the bladder, with secondary deposits in the liver and the abdominal lymph glands, was discovered at necropsy.

The brain weighed $1,440 \mathrm{~g}$. The meninges were opaque over the whole of the vertex, and there was slight generalized convolutional atrophy. Apart from these findings no gross abnormality was noted.

Histologically, the only pathological findings of importance were confined to the cerebellum. In Nissl-stained sections the Purkinje cell layer and the Bergmann layer were well preserved. The granular layer, however, showed varying degrees of degenerative change. Some folia were normal in appearance, whilst in others an almost complete necrosis of the granular layer had occurred. Even the granules less severely affected showed some loss of configuration of the nuclear chromatin, the nuclear membrane being no longer visible and the shape no longer quite rounded. Many cells, however, had almost entirely lost their affinity for cresyl violet, a more or less homogeneous and markedly deformed disk alone remaining. Still more advanced degeneration was indicated by faint shadows of nuclear débris. The Golgi cells of this layer were well preserved, standing out in marked relief amidst the areas of necrosis. In myelin preparations the granular layer was only lightly stained, but did not show the extreme "translucency" of other cases in this series. There was no loss of myelinated fibres, the "light" staining resulting from the poorly stained cell bodies. Silver preparations also showed no loss of fibres in the granular layer, although beading was present. Basket cells and fibres were well preserved. The molecular layer showed no abnormality.

The dentate nucleus was intact, the nerve cells showing 

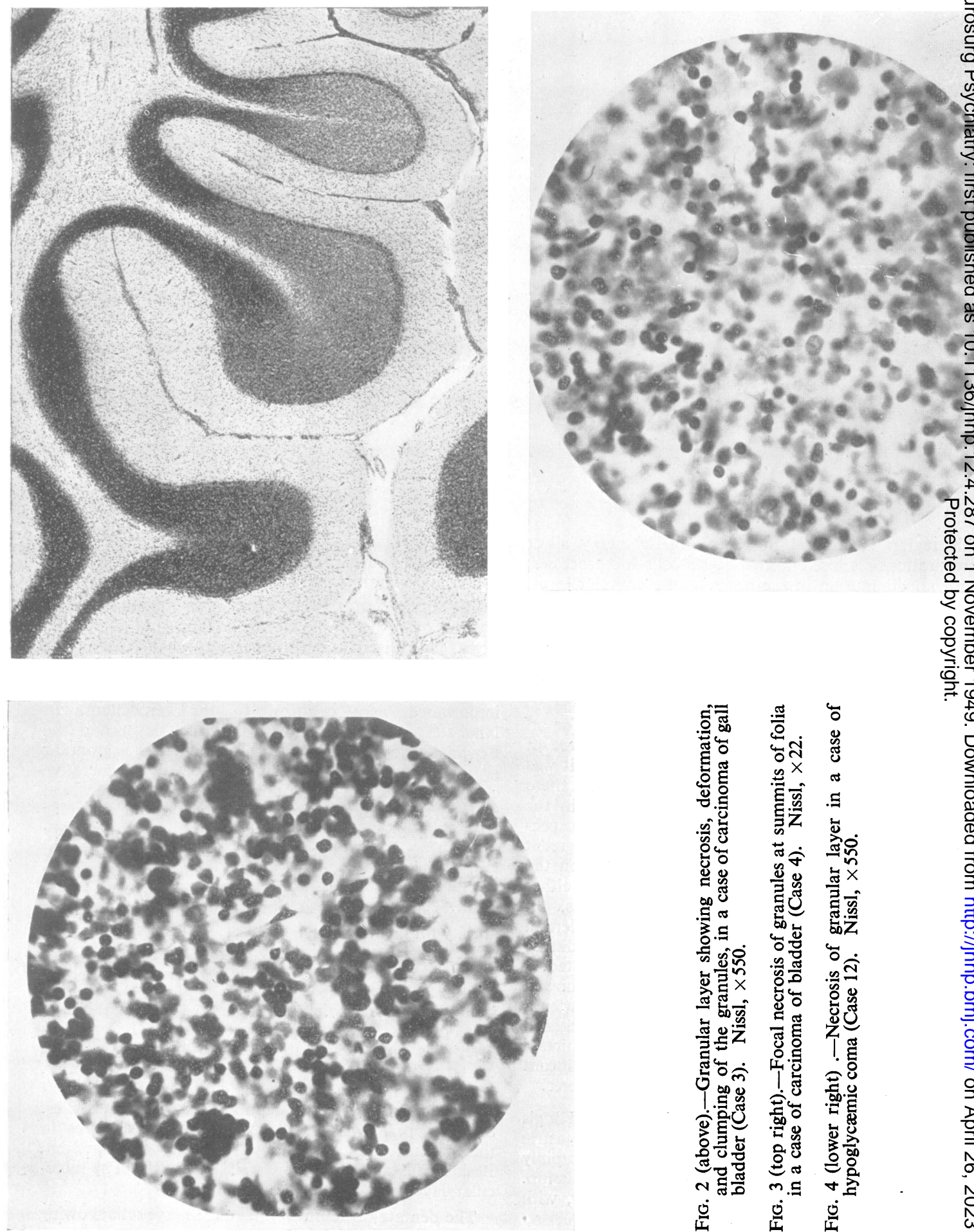

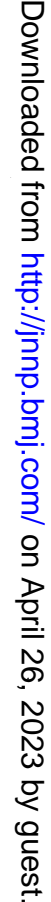



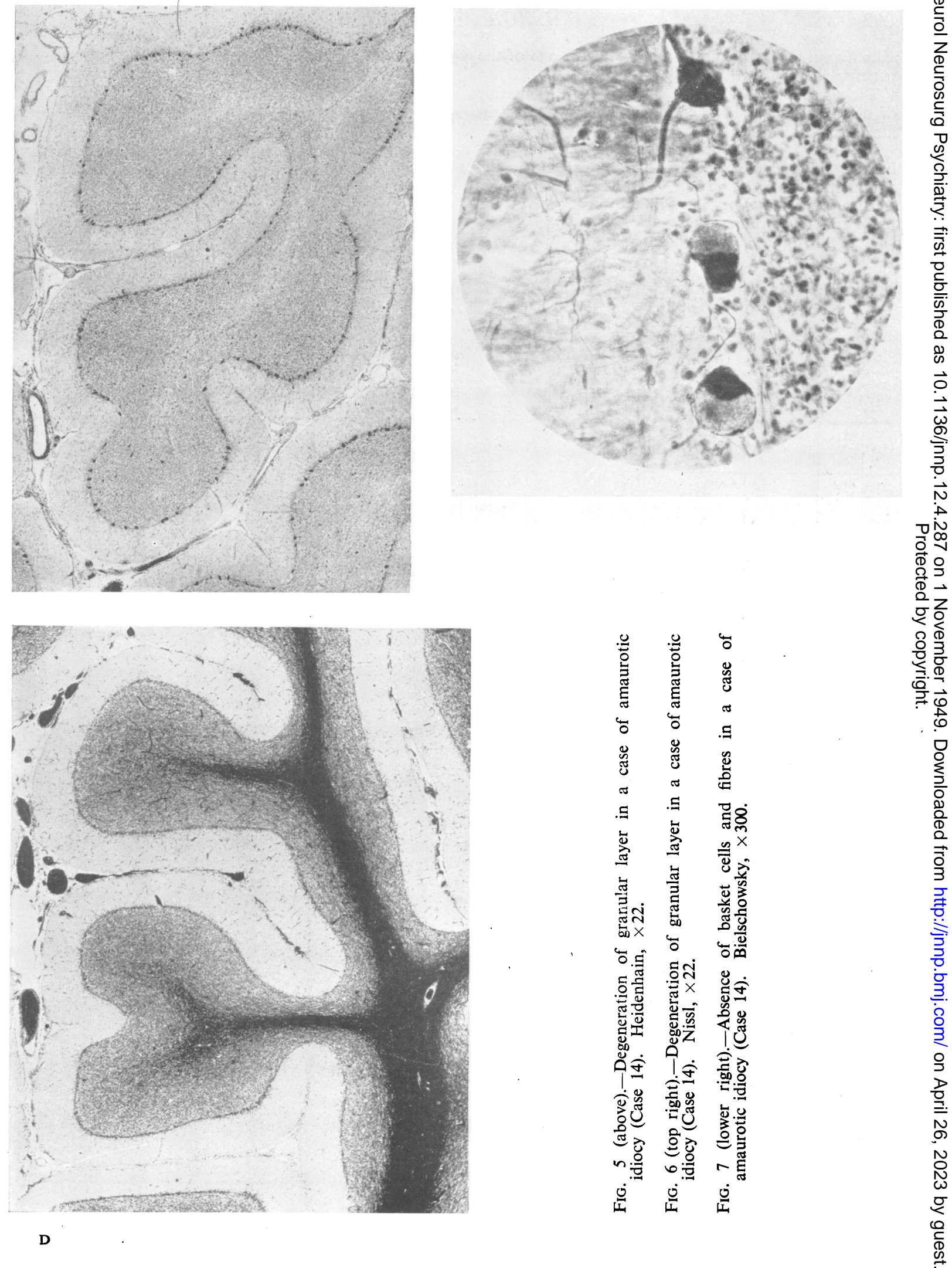
a lipofuscin change commensurate with the age of the patient.

The olives showed a general diminution in the number of nerve cells, all of which showed extreme pigment atrophy.

In Holzer preparations there was gliosis in the cerebellar white matter (but not in the cortex) and in the region of both inferior olives.

There was no abnormality in the remainder of the brain or in its blood vessels.

The remaining six cases showed substantially similar appearances and will not be described in detail. The relevant data appear in Table I.
Group II : Hypoglycæmic and Diabetic Coma

In this group we had four cases. Case 12 is described below in detail, and the relevant data for: the whole group are abstracted in Table II.

Case 12.-A woman aged 30, a diabetic of 8 years duration, was admitted to King's College Hospital in hypoglycæmic coma. In spite of vigorous treatment, she died after a period of coma lasting seventeen days.

Autopsy Findings.-Widespread cavitation of the Swiss-cheese type was seen within the cerebral white? matter and the basal ganglia. This was due to a profuse growth of the gas-forming $\mathrm{Cl}$. Welchii, which was foundō

TABLE I

GRANULAR LAYER DEEGÉNERATION ASSOĊIATED WITH VISCERAL CARCINOMATA

\begin{tabular}{|c|c|c|c|c|c|c|c|c|c|}
\hline Case & $\begin{array}{l}\text { Age } \\
\text { at } \\
\text { death }\end{array}$ & $\begin{array}{c}\text { Duration } \\
\text { of illness } \\
\text { (mths.) }\end{array}$ & $\begin{array}{c}\text { Pathological } \\
\text { diagnosis }\end{array}$ & $\begin{array}{l}\text { Cach- } \\
\text { exia }\end{array}$ & $\begin{array}{c}\text { Secondary } \\
\text { deposits }\end{array}$ & Complications & $\begin{array}{c}\text { Granular } \\
\text { layer } \\
\text { degeneration }\end{array}$ & $\begin{array}{l}\text { Inferior } \\
\text { olive }\end{array}$ & Other C.N.S. abnormalities $\frac{\text { న్ }}{ٍ}$ \\
\hline 1 & 62 & 12 & $\begin{array}{l}\text { Carcinoma of } \\
\text { stomach }\end{array}$ & + & - & $\begin{array}{l}\text { Wernicke's } \\
\text { syndrome; } \\
\text { mania }\end{array}$ & $\begin{array}{l}\text { Generalized, } \\
\text { but more } \\
\text { marked in } \\
\text { dorsal cere- } \\
\text { be l l u m } \\
\text { (Fig. 1) }\end{array}$ & $\begin{array}{l}\text { S e e r e } \\
\text { ch anges } \\
\text { outfall of } \\
\text { nerve cells } \\
\text { in dorso- } \\
\text { medial por- } \\
\text { tion of oli- } \\
\text { vary nucleus }\end{array}$ & $\begin{array}{l}\text { Moderate fibrosis of cerebral } \\
\text { and meningeal blood vessels } \\
\text { producing the appearance of } \\
\text { small "criblures" in the } \\
\text { cerebral white matter. }\end{array}$ \\
\hline 2 & 67 & 6 & $\begin{array}{l}\text { Carcinoma of } \\
\text { bladder }\end{array}$ & + & Hepatic & - & Patchy & $\begin{array}{l}\text { Slight general } \\
\text { nerve-ce } 11 \\
\text { reduction }\end{array}$ & $\frac{D}{\text { D }}$ \\
\hline 3 & 60 & 3 & $\begin{array}{l}\text { Carcinoma of } \\
\text { gall-bladder }\end{array}$ & + & Hepatic & - & Patchy (Fig .2) & $\begin{array}{l}\text { S e e r e } \\
\text { ch a } \mathrm{g} \text { es; } \\
\text { almost com- } \\
\text { plete dis- } \\
\text { appearance } \\
\text { of ner e } \\
\text { cells }\end{array}$ & 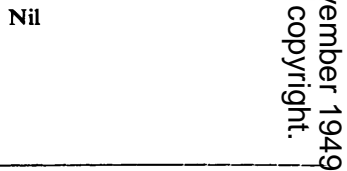 \\
\hline 4 & 66 & 8 & $\begin{array}{l}\text { Carcinoma of } \\
\text { bladder }\end{array}$ & + & - & $\begin{array}{l}\text { Oral signs of } \\
\text { vitamin } \\
\text { deficiency }\end{array}$ & Patchy (Fig. 3) & $\begin{array}{l}\text { Slight general } \\
\text { nerve-ce } 11 \\
\text { reduction }\end{array}$ & $\begin{array}{l}\text { Lipofuscin change in nerve } \\
\text { cells of cerebral cortex } \\
\text { subcortical grey masses, and } \\
\text { brain stem nuclei. Severe } \\
\text { pigment atrophy of cells of } \\
\text { dentate nucleus. Moderate } \\
\text { gliosis in region of dentate } \\
\text { nucleus and in cerebellapi } \\
\text { white matter, and in alb } \\
\text { marginal zones. }\end{array}$ \\
\hline 5 & 66 & 12 & $\begin{array}{l}\text { Carcinoma of } \\
\text { pancreas }\end{array}$ & + & Hepatic & Glycosuria & $\begin{array}{l}\text { Generalized ; } \\
\text { some reduc- } \\
\text { tion in num- } \\
\text { ber of Pur- } \\
\text { kinje cells }\end{array}$ & Normal & Nil \\
\hline 6 & 51 & 6 & $\begin{array}{l}\text { Carcinoma of } \\
\text { breast }\end{array}$ & + & Cerebral & $\begin{array}{l}\text { Mentally } \\
\text { defective } \\
\text { since birth }\end{array}$ & Generalized & $\begin{array}{l}\text { Some general } \\
\text { diminution } \\
\text { of nerve } \\
\text { cells, with } \\
\text { rarefaction } \\
\text { of dorsal } \\
\text { flexure }\end{array}$ & $\frac{5}{5}$ \\
\hline 7 & 53 & 6 & $\begin{array}{l}\text { Carcinoma of } \\
\text { bronchus }\end{array}$ & + & Cerebral & $\begin{array}{c}\text { Korsakow's } \\
\text { psychosis ” }\end{array}$ & Generalized & $\begin{array}{l}\text { Slight general } \\
\text { nerve-cell } \\
\text { reduction }\end{array}$ & Nil \\
\hline 8 & 75 & Unknown & $\begin{array}{l}\text { Carcinoma of } \\
\text { stomach }\end{array}$ & + & - & - & Generalized & Normal & $\begin{array}{l}\text { General pigment atrophy, witb } \\
\text { some reduction of the nerve } \\
\text { cells of the cerebral cortex } \\
\text { Etat crible in putamen and } \\
\text { pallidum. Fibrosis of cerebra仿 } \\
\text { vessels with varying degrees. } \\
\text { of cerebral atheroma. }\end{array}$ \\
\hline
\end{tabular}


TABLE II

DEGENERATION OF THE GRANULAR LAYER ASSOCIATED WITH HYPOGLYCAMIC AND DIABETIC COMA

\begin{tabular}{|c|c|c|c|c|c|c|c|c|}
\hline Case & $\begin{array}{l}\text { Age } \\
\text { at } \\
\text { death }\end{array}$ & $\begin{array}{c}\text { Duration } \\
\text { of } \\
\text { illness }\end{array}$ & $\begin{array}{l}\text { Clinical } \\
\text { diagnosis }\end{array}$ & $\begin{array}{l}\text { Cach- } \\
\text { exia }\end{array}$ & $\begin{array}{c}\text { Complica- } \\
\text { tions }\end{array}$ & $\begin{array}{c}\text { Granular } \\
\text { layer } \\
\text { degeneration }\end{array}$ & $\begin{array}{l}\text { Olivary } \\
\text { nuclei }\end{array}$ & Other C.N.S. abnormalities \\
\hline 9 & 21 & $\underset{60 \text { hours }}{\text { Coma- }}$ & $\begin{array}{l}\text { Hypoglycæmic } \\
\text { coma ; schizo- } \\
\text { phrenia }\end{array}$ & - & - & Diffuse & $\begin{array}{l}\text { Some generalized } \\
\text { reduction in } \\
\text { nerve cells }\end{array}$ & $\begin{array}{l}\text { Widespread severe necrosis in frontal, } \\
\text { parietal, and temporal cortex, and } \\
\text { in Sommer sector and endfolium of } \\
\text { the Ammonshorn. } \\
\text { Dentate nucleus-general cellular } \\
\text { reduction with pigment atrophy of } \\
\text { those nerve cells remaining. }\end{array}$ \\
\hline 10 & 17 & $\underset{36 \text { hours }}{\text { Coma- }}$ & $\begin{array}{l}\text { Hypoglycæmic } \\
\text { coma; schizo- } \\
\text { phrenia }\end{array}$ & - & 一 & $\begin{array}{l}\text { Diffuse ; Pur- } \\
\text { kinje cells } \\
\text { showed acute } \\
\text { cell change }\end{array}$ & No abnormality & $\begin{array}{l}\text { Foci of cellular necrosis in the fifth } \\
\text { and sixth layers of the frontal, } \\
\text { parietal, and temporal cortex. The } \\
\text { Sommer sector and endfolium of } \\
\text { Ammonshorn were almost devoid of } \\
\text { nerve cells. }\end{array}$ \\
\hline 11 & 10 & $\begin{array}{l}\text { Coma- } \\
\text { ? dura- } \\
\text { tion }\end{array}$ & $\begin{array}{l}\text { ? Hypoglycæmic } \\
\text { coma;?hyper- } \\
\text { g } 1 \text { y c æ m i c } \\
\text { coma ; dia- } \\
\text { betes mellitus }\end{array}$ & - & $\begin{array}{l}\text { Epileptic } \\
\text { attacks } \\
\text { s in e e } \\
\text { age } 6\end{array}$ & Diffuse & No abnormality & $\begin{array}{l}\text { Sector necrosis of Ammonshorn, } \\
\text { marginal gliosis of the cerebral } \\
\text { cortex, and some perivascular and } \\
\text { diffuse gliosis within the cerebral } \\
\text { white matter. }\end{array}$ \\
\hline 12 & 30 & $\underset{17 \text { days }}{\text { Coma- }}$ & $\begin{array}{l}\text { Hypoglycæmic } \\
\text { coma ; dia- } \\
\text { betes mellitus }\end{array}$ & - & - & Diffuse (Fig. 4) & No abnormality & See full case report. \\
\hline
\end{tabular}

inside the blood vessels and the adjacent tissues. There was no inflammatory reaction to the bacillary invasion, so that it must have occurred immediately before, or just after, death. Histologically there was widespread loss of nerve cells in the cerebral hemispheres, with a corresponding microglial and neuroglial reaction. These pathological findings have been reported in full elsewhere (Lawrence and others, 1942) and were considered to be the result of the prolonged cerebral anoxia.

The cerebellum showed a typical granular layer degeneration which had not been noticed at the time of the earlier publication. In Nissl preparations the Purkinje cells were well stained and in no way abnormal. The granules, however, were thinned out, many cells showing complete disappearance of their nuclei, and staining homogeneously with basic dyes (Fig. 4). This change in the granular layer was present throughout the cerebellar cortex. In myelin stains the pale grey appearance of this layer contrasted with the darkly staining layer of Bergmann glia. Silver impregnation showed preservation of basket cells and fibres, with no diminution in the fibres of the granular layer. In Scharlach $\mathbf{R}$ sections some increase in lipoids could be seen in the histiocytic and microglial cells, in both the Bergmann and granular layers. No fibrous gliosis was observed with the Holzer technique in any of the cerebellar layers.

The dentate nucleus and the olives of this brain were not available.

TABLE III

GRANULAR LAYER DEGENERATION IN AMAUROTIC IDIOCY

\begin{tabular}{|c|c|c|c|c|c|c|c|c|}
\hline Case & $\begin{array}{c}\text { Age } \\
\text { at } \\
\text { death }\end{array}$ & $\begin{array}{l}\text { Duration } \\
\text { of } \\
\text { illness }\end{array}$ & $\begin{array}{l}\text { Clinical } \\
\text { diagnosis }\end{array}$ & $\begin{array}{l}\text { Cach- } \\
\text { exia }\end{array}$ & $\begin{array}{c}\text { Complica- } \\
\text { tions }\end{array}$ & $\begin{array}{c}\text { Granular } \\
\text { layer } \\
\text { degeneration }\end{array}$ & $\begin{array}{c}\text { Olivary } \\
\text { nuclei }\end{array}$ & Other C.N.S. abnormalities \\
\hline 13 & 19 & $\begin{array}{c}\text { Several } \\
\text { years }\end{array}$ & $\underset{\text { idiocy }}{\text { Amaurotic family }}$ & + & Epileptic fits & $\begin{array}{l}\text { Diffuse ; gliosis } \\
\text { present }\end{array}$ & Not available & $\begin{array}{l}\text { "Ballooning" of nerve cells } \\
\text { throughout the brain charac- } \\
\text { teristic of amaurotic idiocy }\end{array}$ \\
\hline 14 & 15 & $\begin{array}{l}\text { Several } \\
\text { years }\end{array}$ & $\underset{\text { idiocy }}{\text { Amaurotic family }}$ & + & $\begin{array}{l}\text { Hypostatic } \\
\text { pneumonia } \\
\text { epileptic } \\
\text { fits }\end{array}$ & $\begin{array}{l}\text { Diffuse } \\
\text { 5, 6). } \\
\text { present }\end{array}$ & $\begin{array}{l}\text { Severely affected, } \\
\text { loss of nerve } \\
\text { cells particularly } \\
\text { in dorsomedial } \\
\text { p or } t \text { i o n of } \\
\text { nucleus }\end{array}$ & $\begin{array}{l}\text { "Ballooning" of nerve cells } \\
\text { throughout the brain charac } \\
\text { teristic of amaurotic idiocy. }\end{array}$ \\
\hline 15 & ? & $\begin{array}{c}\text { Several } \\
\text { years }\end{array}$ & $\begin{array}{l}\text { Amaurotic family } \\
\text { idiocy }\end{array}$ & + & $\begin{array}{l}\text { No clinical } \\
\text { notes avail- } \\
\text { able }\end{array}$ & $\begin{array}{l}\text { Diffuse ; gliosis } \\
\text { present }\end{array}$ & No abnormality & $\begin{array}{l}\text { "Ballooning" of nerve cells } \\
\text { throughout the brain charac } \\
\text { teristic of amaurotic idiocy. }\end{array}$ \\
\hline 16 & 19 & $\begin{array}{c}\text { Several } \\
\text { years }\end{array}$ & $\begin{array}{l}\text { Amaurotic family } \\
\text { idiocy }\end{array}$ & + & $\begin{array}{l}\text { No clinical } \\
\text { notes avail- } \\
\text { able }\end{array}$ & $\begin{array}{c}\text { Patchy; severe } \\
\text { outfall of Pur- } \\
\text { kinje cells; } \\
\text { gliosis present }\end{array}$ & Not available & $\begin{array}{l}\text { "Ballooning" of nerve cells } \\
\text { throughout the brain charac } \\
\text { teristic of amaurotic idiocy. }\end{array}$ \\
\hline
\end{tabular}




\section{Group III : Amaurotic Idiocy}

Again four cases were available for examination. Case 14 is described in full, and Table III summarises the remainder.

Case 14. - A boy was admitted to hospital at the age of 11 years. He was blind and suffered from epileptic attacks. He deteriorated slowly for four years, becoming bedridden and incontinent. He finally died at the age of 15 , as a result of hypostatic pneumonia.

Autopsy Findings.-No macroscopic abnormality was recorded in the brain. Histological examination disclosed ballooning and lipoid infiltration in the nerve cells throughout the nervous system. In the cerebellum a granular layer degeneration was present. With myelin techniques the characteristic "lightening" of the granular layer was clearly demonstrated (Fig. 5). In Nissl sections the Purkinje cells, though globular in shape and infiltrated with lipoid material, stained well, and showed no diminution in number. In contrast, hardly a normal granule cell could be found throughout the whole cerebellar cortex (Fig. 6). The Golgi cells of this layer, however, had survived intact. The Bergmann glia was not proliferated. In Holzer preparations a slight fibrous gliosis was seen in the white matter of the lobules and around the dentate nucleus. In the granular and molecular layers there was a considerable astrocytic gliosis.

Bielschowsky silver preparations showed almost complete disappearance of basket cells and their fibres (Fig. 7). The radial fibres of the molecular layer were absent. The dendritic processes of the Purkinje cells and their axones showed no abnormality. In the granular layer there was great diminution in the nerve fibres.

The cells of the dentate nucleus were not diminished in number, but showed well marked "ballooning" and lipoid infiltration.

In the medulla the inferior olives proved to be severely affected. With low magnification a general diminution in cells was at once apparent, whilst in the dorsomedial portion of the nucleus hardly a nerve cell remained. With higher magnification the remaining cells showed much lipoid infiltration, with distortion of their cell bodies. Holzer preparations disclosed a fibrous gliosis in the region of both inferior olives.

\section{Discussion}

In the first place it should be emphasized that we have excluded any case in which the pathological signs of degenerative changes in the granular cells were questionable. Faint staining with the Nissl method alone, without the phenomena of conglutination, deformation, or other nuclear or cytoplasmic signs of cell degeneration, was never considered as pathognomonic, as this may be a staining artefact, particularly in brains which have been long in formalin. As it happens, most of our material was embedded soon after fixation in formalin was completed. Comparison with other staining methods, especially myelin stains, was helpful in the evaluation of the changes.

Even after the application of such rigid criteria, our results constitute an impressive confirmation of the claims of Bertrand and his associates, particularly with regard to the carcinoma group, in which eight out of fourteen cases showed this type of degeneration. In the diabetic and hypoglycæmic group our results differ from those of Bertrand and his associates, for in two cases of undoubted diabetic $\stackrel{\vec{\rho}}{\rightarrow}$ coma the granular layer was normal. In three of $\bar{c}$ the remaining four cases death was due to irreversible hypoglycæmic coma ; in two cases it occurred in non-diabetic schizophrenic patients. This is, to our $\mathbb{\mathbb { D }}$ knowledge, the first report of the occurrence of selective degeneration of the granular layer in irreversible hypoglycæmic coma. The change was. found in three of nine fully investigated cases of hypoglycæmic coma.

The results in our four cases of amaurotic idiocy confirm the finding first established by Bielschowsky (1920), of a frequently selective affection of the $\vec{N}$ granular layer in this condition.

The histological detail of the degeneration of the granular layer requires little comment. In af respects this agrees with previous descriptions and in particular with that given by Bertrand and otherg (1942), Williams (1934), Winkelman (1943), an Meyer (1944). In all of our three groups of cases the changes range from early conglutination to $\frac{1}{8}$ complete necrosis of the granule cells. The changes. were either focal, as in Case 3 (Fig. 2), in which only $\vec{\theta}$ a few lobules were affected, or diffuse (Fig. 1), the latter being the more common finding. Even with such a diffuse change, however, there was a not inconsiderable variation in the severity of the lesion from one lobule to the other. In view of these observations it is difficult to draw a sharp dividing line between focal and diffuse varieties of cerebellar atrophy, as was done by Brouwer and Biemond (1938). These authors regard delayed cerebellar atrophy as an example of the former, and the carcinomatous group as an example of the latter. It may be that the cerebellar degeneration occurring with carcinomata, and with other diseases, tends eventually to become diffuse. The same reservation applies to the predilection of the degeneration for the dorsal and medial aspects of the cerebellum, a feature which has been consistently reported in many examples of the delayed Marie-Foix-Alajouanine variety. Bertrand and his associates also observed this selective incidence in the majority of their cases associated with carcinoma and diabetes, but in our material a relative preservation of the ventral parts was seen on only two occasions. Thus, there is no absolute affinity for the dorsal parts of 
the cerebellum at least in the carcinomatous and diabetic variety of cerebellar lesion; it seems more likely that such a transitional distribution tends to occur during the evolution of the process.

Likewise, when we speak of a selective degeneration of the granular layer this does not mean that the lesions were absolutely confined to this part of the cerebellum. In fact, in one of the carcinoma group (Case 5), and one of the amaurotic group (Case 13) the Purkinje cells were slightly reduced in number. There was a more severe loss of Purkinje cells in another of the amaurotic cases (Case 16) and, lastly, in one hypoglycæmic case the Purkinje cells showed very marked acute chromatolysis (Case 10). Evidently, the predilection for the granules is not absolute. This may explain why in some of the carcinoma cases reported in the literature (for example, Zülch, 1936 ; Brouwer and Biemond, 1938) damage was actually more conspicuous in the Purkinje cells than in the granular layer. In the delayed Marie-Foix-Alajouanine group the Purkinje cell affection is usually the main feature, although Garcin and others (1940) reported particularly severe degeneration of the granules.

A striking feature in all our cases associated with carcinoma, hyperglycæmia, and hypoglycæmia, is the absence of an appreciable glial proliferation within the granular layer or other parts of the cerebellar cortex. In some cases there was a moderate gliosis of the white matter. This absence of glial proliferation was also remarked upon by Bertrand and his colleagues. For this reason, and because no cerebellar signs were noted during life, these authors concluded that the cerebellar degeneration occurred in the terminal phase of the disease, for instance, during the terminal cachexia of the patients suffering from carcinoma. It will be remembered that in none of our carcinoma or diabetic-hypoglycæmic cases were clinical signs of disturbed cerebellar function noted. If these cases without glial fibrosis are to be regarded as cases of recent cerebellar degeneration, glial fibrosis should be marked in cases which had exhibited signs of cerebellar dysfunction for some time. There was in fact such a glial fibrosis in all our four amaurotic cases. Unfortunately no reliable clinical data are available to us, but in Norman's (1940) cases of mental defect cerebellar signs had been present for at least the last years of life, and there was very extensive glial sclerosis of all layers of the cerebellar cortex.

At the present juncture it is not possible to offer more than tentative suggestions as to the possible pathogenesis of this type of cerebellar degeneration. It seems that a factor is involved which must be common to such widely different conditions as somatic carcinoma, hyper- and hypoglycæmic coma, and lipoidosis. Courville and Friedman (1940) in discussing the pathogenesis of the delayed (parenchymatous) cerebellar atrophies (in their terminology " chronic progressive degeneration of the superior cerebellar cortex") suggested that circulatory disturbances produced by arachnoidal thickening were of importance. We have examined the brain of a patient (not included in this series) where, in addition to generalized granular degeneration there was a severe, focal change in the neighbourhood of a subarachnoid hæmorrhage. Quite clearly in this case, circulatory disturbances resulting from the hæmorrhage had played a part in producing a focal granular degeneration. However, it is not clear by what mechanism the focal lesion was produced, and indeed in all the cases reported here there was no evidence of a disorder of the blood vessels. Both vasomotor disturbances and defective utilization of oxygen by the tissues may be of importance; indeed, it was considered that such mechanisms were intimately concerned in the production of the cerebral lesion found in hypoglycæmic coma (Lawrence and others, 1942). It is possible that hypoxia arises during the terminal phase of the illness in patients suffering from carcinoma. However, in view of the chronicity of the lesion, it is more clifficult to postulate that circulatory disturbances or anoxia occurred in amaurotic idiocy. Nor would it be easy to explain why the brunt of the degeneration should have fallen on the granules rather than on the Purkinje cells, which, since Spielmeyer's observations (1922), have so often been shown to be especially susceptible to oxygen want. In a fairly large series of cases of all types of anoxic conditions that have been investigated in this laboratory the granules usually remain intact, whereas the Purkinje cells frequently show the characteristic homogenizing changes. Clearly anoxia alone is not a factor likely to be of ætiological significance.

It might be expected that such a comparatively well-defined metabolic disorder as amaurotic family idiocy would throw some light on the ætiology of the granular layer change. In fact, however, so little is known of the metabolic processes that occur in this condition that it would be speculative to ascribe the granular layer degeneration to any specific factor. However, it may be said that in both our carcinoma group and amaurotic idiocy group, cachexia was a marked feature as in other cases reported in the literature (Lhermitte, 1922 ; Zülch, 1936; Norman, 1940; Buchanan and others, 1947). Enteritis, alcoholism and cirrhosis hepatis, which might also be expected to lead to profound metabolic disorder, were also prominent 
in the cases reported by Murri (1900); Rossi (1907); Lhermitte (1922); Lüthy (1930); Zülch (1936) ; Norman (1940), and Alessi (1940).

What is known about the biochemistry of this terminal cachexia does not lend itself to even a tentative hypothesis. In Case 1 the combination of granular layer degeneration with the Wernicke's syndrome suggested a thiamine deficiency, as did Upner's experimental findings ; but both conditions, clearly, occur more frequently independently than in combination. The relationship of olivary changes to thiamine deficiency appeared, however, to be more consistent. While the inferior olives are known to be very reactive to all kinds of noxious agencies, previous analysis of the literature and personal experience led one of us to assume that olivary damage frequently occurs in conditions associated with metabolic and, in particular, with nutritional disturbances (Meyer, 1944). Particular attention was, therefore, paid to the incidence of olivary changes in the present material, but, again, although the two lesions frequently occur together, they occur too often independently to encourage the assumption of a common specific factor. Pellagra also can be excluded; there was not one case in our histologically verified Pellagra material of about twenty cases which showed degeneration of the granular layer or of the olives.

While there is thus the suggestion that a deficiency factor is concerned in the æatiology of the granular layer degeneration, it is clear that a final solution of the problem must await further investigations.

\section{Summary}

Selective degeneration of the granular layer of the cerebellum is described in eight cases of visceral carcinoma, four cases of hypo- or hyperglycæmic coma, and four cases of amaurotic idiocy. The pathogenesis of the lesion is at present obscure, but attention has been directed in this paper to the possibility that some disturbance of metabolism, possibly a nutritional deficiency, is responsible for the degeneration.
It is impossible to make individual acknowledgments to the staff of the various mental hospitals from which we have received the brain material, but we should like to record our special gratitude to Prof. H. A. Magnus of King's College Hospital, who supplied us with the majority of the carcinoma and diabetes cases.

\section{REFERENCES}

Alessi, D. (1940). Riv. Patol. Nerv. Ment., 55, 148.

Archambault, La S. (1918). J. Nerv. Ment. Dis., 48, 273. Bertrand, I., and Godet-Guillain, J. (1942). C.R. Soc. Biol. Paris, 136, 664.

B , and Tiffeneau, R. (1942). Ibid., 136, 500.

Bielschowsky, M. (1920). J. Psychol. Neurol., 26, 123.

Brouwer, B., and Biemond, A. J. (1938). J. Belge Neurol., 38, 691 .

Buchanan, A. R., Overholt, L. C., and Neubaerger, N. T. (1947). J. Neuropath. exp. Neuroi., 6, 2, 152.

Casper, J. (1929). Z. ges. Neurol. Psychiat., 33, 854, 885-6.

Courville, C. B., and Friedman, A. P. (1940). Bull. Los Ang. Neurol. Soc., 5, 171.

Ferraro, A., and Morrison, R. (1928). Psychiat. Quart., 2,506 .

Foix, C., Marie, P., and Alajouanine, T. (1922). Rev.

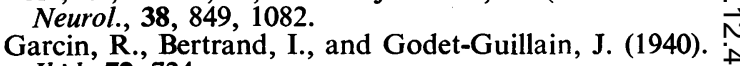
Ibid., 72, 724.

Greenfield, J. G. G. (1934). Brain, 57, 161.

Hunter, D., Bomford, R. B., and Russell, D. S. (1940 Quart. J. Med., n.s.9, 193.

Kennard, M. (1935). Proc. Kon. Akad. van Wetensch Amsterdam, 38, 544.

Lawrence, R. D., Meyer, A., and Nevin, S. (1942妥 Quart. J. Med., 11, 181.

Lhermitte, J. (1922). Rev. Neurol., 38, 313.

Lüthy, F. (1930). Z. Neurol., 57, 319.

Meyer, A. (1932). Z. ges. Neurol. Psychiat., 139, 422.

(1944). J. Neurol., Neurosurg. Psychiat., 7, 66.

Murri, A. (1900). Riv. Crit. Clin. Med., 1, 593.

Norman, R. M. (1940). Brain, 63, 365.

Parker, H. L., and Kernohan, J. W. (1933). Ibid., 56, 191.

Rossi, I. (1907). Nouv. Iconog. Saltpet., 20, 66.

Scherer, H. J. (1931). Z. ges. Neurol. Psychiat., 136, 559. (1933). Ibid., 145, 335.

Shinosaki, T. (1926). Ibid., 106, 483.

Spielmeyer, W. (1925). Ibid., 99, 756.

Upners, T. (1939). Ibid., 166, 623.

Williams, E. Y. (1934). Arch. Path., 17, 206.

Winkelman, N. W. (1943). J. Neuropath. exp. Neurol., $2,413$.

Zülch, K. J. (1936). Z. ges. Neurol. Psychiat., 156, 493, 573.

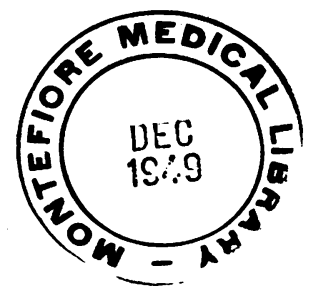

